Article

\title{
Indicators for Assessing the Sustainability of Built Heritage Attractions: An Anglo-Chinese Study
}

\author{
Wei Ren and Feng Han* \\ College of Architecture and Urban Planning, Tongji University, Shanghai 200092, China; \\ wei.ren@tongji.edu.cn or wei.ren1012@foxmail.com \\ * Correspondence: 88163@tongji.edu.cn; Tel.: +86-135-0161-0876
}

Received: 21 May 2018; Accepted: 11 July 2018; Published: 17 July 2018

\begin{abstract}
Although sustainability is now a well-established concept, it is less well-established in the management of built heritage attractions. This paper reports research on the application of sustainability indicators for built heritage attractions, as a means to advance a more holistic sustainability assessment approach for the management of this important type of attraction. The research employed a questionnaire-based survey and four case studies designed to provide information concerning sustainability assessment for a substantial sample of built heritage attractions in both the UK and China. It seeks to identify the dimensions of sustainability for such attractions through a consideration of relevant sustainability indicators. The research findings indicate important variations in terms of the importance of key sustainable indicators between the UK and China. The results also provide pointers as to how the set of indicators might be developed further to provide a more holistic and measurable appraisal method to assess the sustainability of the management of built heritage attractions.
\end{abstract}

Keywords: indicators; sustainability; built heritage; sustainable tourism; the UK; China

\section{Introduction}

"Built heritage" refers to historic buildings and sites which have been preserved and which have architectural, historical, or other significant value. A growing number of such sites have become involved in the tourism industry and serve as practical tools for urban and rural regeneration. The term "heritage" was defined as "almost any sort of intergenerational exchange or relationship, welcome or not, between societies as well as individuals" [1]. However, heritage could be used for a wide range of modern purposes [2]. For many authorities, the transfer from built heritage to tourist attraction is one of the major facets of the tourism industry. It provides a possible alternative means of achieving economic development, employment creation and heritage conservation. Nevertheless, the realities of heritage tourism should be recognized, especially concerns regarding environmental protection and the types of employment involved.

Although there is global acceptance of the concept of "sustainability", the scope and nature of this term are somehow confused territory. One of the most significant definitions of "sustainability" is reflecting the importance of economic, environmental and social factors in decision-making [3]. Heritage and tourism are closely linked; identity, culture and preservation contribute to the durability of supply and reinforce stakeholder inclusion and economic, social, environmental and cultural dimensions [4]. Hence, the assessment of synergies among these factors shows certain challenges. The application of indicators is a significant vehicle for assessing sustainability. Initial indicators for sustainable tourism have been developed by various organizations and scholars [5-11]. In practice, there are few indicators which are universally accepted for the appraisal of the sustainability of built heritage attractions [11]. This research aimed to define the sustainability of built heritage attractions 
by proposing a set of built heritage sustainability indicators and examining their relative importance for heritage attraction site managers in the UK and China through a questionnaire approach. Then, it compared sustainability of built heritage attractions between the UK and China by a case study approach: two sites in the UK; and two sites in China. The paper first reviews existing research on the relationship between built heritage tourism, sustainability appraisal and sustainability indicators, and introduces the methodology in terms of the questionnaire design and case study, distribution and data collection, as well as the research findings.

Cross-national comparisons are employed in this research to examine the variations in assessment by attraction managers of sustainability indicators for built heritage attractions in both less developed (China) and developed (the UK) countries. At the stage of research design, this research considered selecting China, Japan, India, the UK, Italy, France or Germany to carry the research, but China and the UK were the final choices for four reasons. The first relates to economic criteria. The World Bank defines the gross national income (GNI) per capita of a country over US\$12,275 as a "developed" country while countries with a GNI below this figure are classified as "less developed" (World Bank, 2012). The GNI per capita of China is US $\$ 7536$, while the GNI per capita of the UK is US\$35,860 [12]. Therefore, China is categorized as a less developed country and the UK is categorized as a developed country according to their GNI. A second reason is the comprehensiveness of the built heritage in each country. China has 52 World Heritage sites of which 36 are cultural heritage sites and 4 are mixed heritage sites; there are also a large number of heritage attractions which have not been nominated but which still have unique significance. By comparison, the UK has 31 World Heritage sites of which 26 are cultural heritage sites [13]. The third consideration is the accessibility of data. The corresponding author of this paper was born and worked in China before 2011; therefore, he has the language skills and connections to carry out the research in both countries. The fourth reason is that both China and the UK can represent the unique cultural and social systems in the east and west, respectively.

\section{Context: Sustainable Tourism, Indicators and Built Heritage Attractions}

\subsection{Recognition of the Importance of Sustainable Tourism}

The tourism industry is a fast growing industry across much of the world. However, many negative tourism impacts such as environmental degradation, economic leakage, economic dependence and threats to local customs and culture are claimed as the direct and indirect results of global tourism [14-17]. The World Commission on Environment and Development proposed that sustainable development should meet the needs of the present without compromising the ability of further generations to meet their own needs [18]. Murphy [19] claimed that sustainable tourism should be aimed at maintaining cultural integrity, essential ecological processes and biological diversity and life support systems. Hall [20] argued that sustainable tourism demands long-term commitment by all parties in terms of social, environmental and economic factors. The concept of sustainable tourism has been developed and promoted by many scholars and organizations [20-22]. However, whilst the concept has been strongly promoted, most tourism destinations and attractions have failed to meet the requirements of sustainable development, partly as a result of vested economic interests. Orbasli [23], for example, reported that tourism operators and attractions are trying to look "green", and the term "environmentally friendly tourism" is promoted as part of a marketing strategy to meet customers' demands.

The traditional three pillars of sustainability are economic development, social development and environmental protection. They are so closely linked that the measurement of, and planning for, tourist impacts are rendered complex and difficult [15]. There is also the dimension of governance. United Nations Development Programme (UNDP) [24] defines the term "governance" as managing economic, political and social affairs through interactions within and among the state, civil society and private sector. When tourism is integrated into heritage conservation as a poverty reduction strategy, 
the indicators of the governance dimension can play a significant role in measuring the performance of the private and public sectors.

\subsection{The Application of Sustainability Indicators}

Sustainability assessment for built heritage attractions can be employed to assess their effectiveness and efficiency in terms of sustainable development. One approach is to list a series of different assessment tools and then select the best assessment tools after comparing the different alternatives [25-27]. Debates on how to apply sustainability assessment have existed since the concept of sustainability was developed [28-30]; however, the quality of sustainability assessment has been criticised as having limited alternatives, unclear options and being biased towards predetermined solutions [31]. Indicator-based approaches are associated with the selection of different sustainability indicators and their weighting, normalization and aggregation [27].

\subsection{Heritage Tourism and Sustainability}

The very concept of heritage tourism raises strong and divergent views. Urry [32], for example, claimed that cultural values are over compromised for commercial gain. However, as a co-operation theory perspective, McKercher and Du Cros [33] suggested that both heritage and tourism can achieve mutually beneficial outcomes by sharing partnership opportunities. Heritage tourism can provide visitors with the experience and knowledge to appreciate the historic environment; the core tourism product within this is built heritage attractions. Cultural and historical tourism has become one of the fastest and largest growing sectors in this industry $[34,35]$. Built heritage attractions may ensure the conservation and protection of heritage and its presentation and transmission to future generations.

Debates on the scope of built heritage sustainability concern conservation, facilities, environment, governance and other factors. For example, Bizzarro and Nijkamp [36] identified five critical elements for achieving a sustainable conservation policy: hardware (e.g., facilities); software (e.g., knowledge); eco-ware (e.g., environmental amenities); fin-ware (e.g., financial support); and org-ware (e.g., institutional support systems). Heritage sustainability should cover the physical maintenance of resources and a comprehensive review of its cultural and social relevance [14]. Governance is a significant factor in achieving sustainability. Matero [37] concluded heritage sustainability should enable the contribution of heritage to the present by considerate management. Rodwell [38] indicated three sustainable conservation principles: ensuring the continuity of supply by the wise use of resources; minimum interventions to the fabric and cultural identity; and constructive evolution as opposed to destructive revolution. From a non-governmental organization (NGO) perspective, the UNESCO world heritage and sustainable tourism programme focuses on four areas: sustainable tourism policy and strategy development; sustainable tourism tools; capacity building activities; and heritage routes [39].

\subsection{Sustainability Appraisal of Built Heritage Attractions}

This research defined built heritage attractions as inherited sites which can be promoted as heritage tourism products. Four dimensions of heritage tourism impacts have been identified: economic, social, environmental and governance. Economic impacts encompass the monetary benefits and costs that result from the development and use of tourism facilities and services. Environmental impacts include alterations to the natural environment including air, water, soils, vegetation, and wildlife, as well as changes in the built environment [15]. Mason [17] suggested that the revenue generated from tourism maintains the attractions, enhances the interest and willingness to protect the environment and promotes the establishment of national parks and the preservation of buildings and monuments. Social impacts may also arise with tourism development; for example, tourists may contribute to congestion in terms of overcrowding as well as increased traffic; there may be a revival of traditional arts or other handicraft activities; there may be some revitalization of poor or non-industrialized regions; and there may be a loss of cultural identity, overcrowding in resort areas, and a reduction in 
the diversity of global culture. Built heritage tourism is becoming a driving force within sustainable development, and the effectiveness of built heritage attraction governance should be monitored to assess its performance.

Assessment are normally proposed actions (projects, programmes, plans, or policies) [40]. Sustainability indicators provide critical benchmarks against which to measure tourism impacts across the four dimensions, helping to track progress towards relevant objectives [25]. Although several sets of sustainability indicators have been proposed, few have been universally accepted, mainly because of the scale and the variability of the contexts of sustainability [41]. Most sustainability indicators are used at international, national and regional destination levels [42]; few sets of indicators are specifically designed for measuring locational very specific built heritage attractions.

Nocca (2017) conducted a frequency analysis of indicators of 40 case studies and subdivided these indicators into nine impact categories, with each impact's category composed of indicator sub-categories [4]. The UNWTO developed forty baseline indicators and other indicators in its Indicators of Sustainable Development for Tourism Destinations [8]; however, their indicators are mainly used at the broader tourist destination level rather than for specific attractions. Other sustainable tourism indicators proposed include the Green Globe certification [43], Tourist Attraction Rating Categories of China by the China National Tourism Administration [44]; and tourism indicators by the European Environment Agency [5]. The limitation of such indicator sets is that they over-emphasise the current situation and have little consideration of future issues. Further, such indicators tend to focus more on evaluating sustainable tourism in terms of national destinations, rather than individual attractions. Stubbs [7] developed a framework for developing sustainability indicators at historic sites; his four topic areas comprise the environmental, social and cultural, economic and generic. Further research proposals for a set of qualitative and quantitative indicators or for developing a tailor-made approach to the measurement of heritage-sustainability are lacking.

\section{Methodology}

\subsection{Developing an Indicator Set}

The application of indicators in heritage conservation and tourism management can help to achieve more sustainable development. However, most sustainability indicators are used at the level of tourist destinations [42]; few sets of indicators are designed for specifically measuring built heritage attractions.

Drive-Pressure-State-Impact-Response (DPSIR) is a causal framework for describing the interaction between the environment and human activities. This sequence model moves from demand being the driving force to environmental pressure, which leads to a change in state, which then increases the impact and concludes with a final response [45]. In this research, the driving force is the human resource to develop built heritage assets, turn them into tourist attraction and meet tourism demands. The pressure of tourism directly affects the environment and the built heritage attraction itself. The impacts are the effects on the built heritage attractions' development, which will be analysed through the dimensions of sustainability. The response is how to deal with the issues, and the recommendations to be made as a result of this research.

The set of indicators used in the research was revised three times since it was first developed (Figure 1). The first time was a shortlist of indicators based on a combination of material from relevant indicator sets in the literature, and feedback from practice. A set of fourteen sustainability indicators was designed specifically for assessing the sustainability of built heritage attractions. The second time was at the stage of assessing the pilot study and the final time was at the stage of assessing main case studies. The indicators cover the four key dimensions of sustainable development: economic, social, environmental and governance. The indicators are listed in Appendix ??, along with the reasons for selection. 

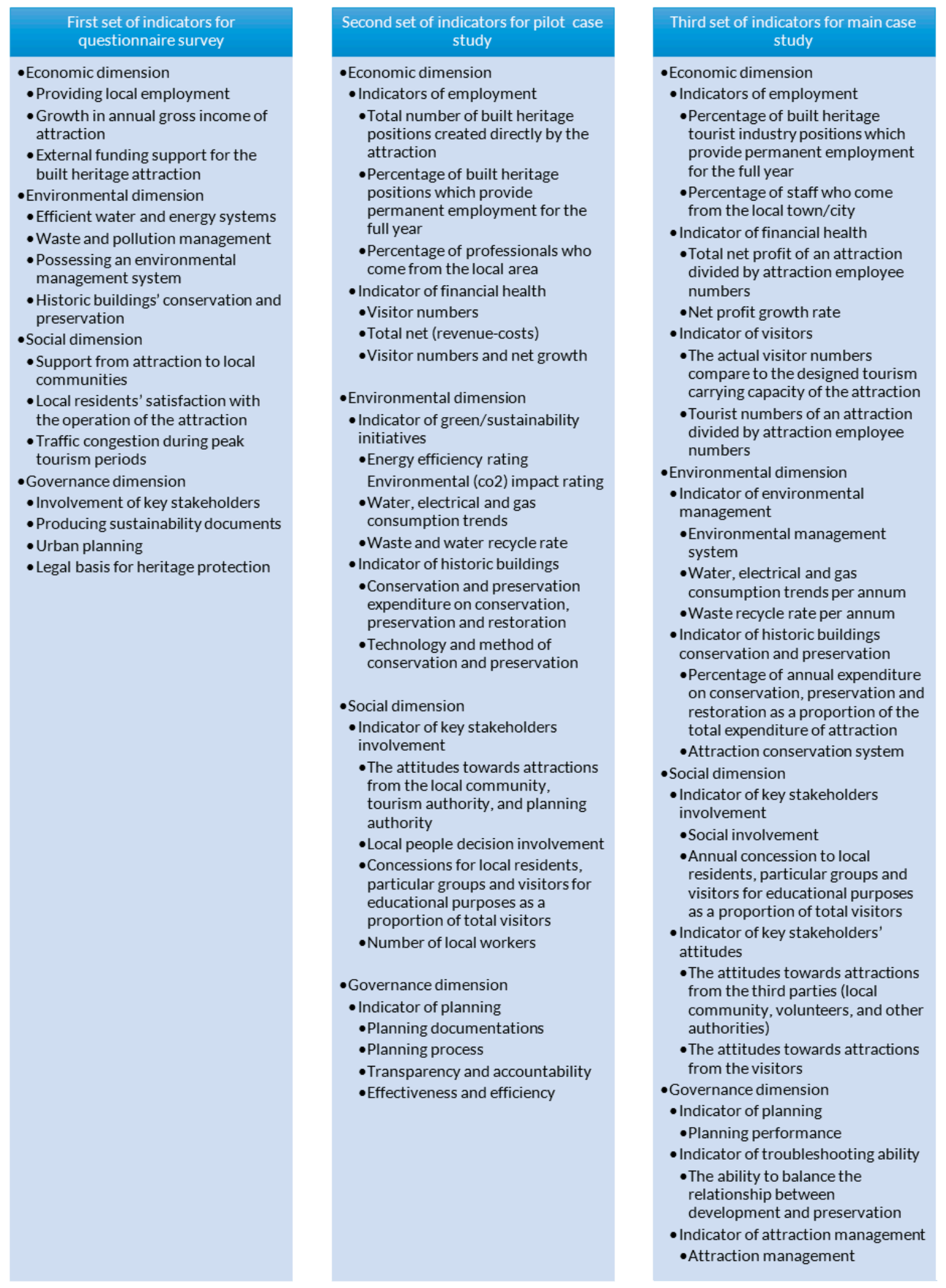

Figure 1. Development of indicators in this research. 


\subsection{Selecting the Questionnaire Survey Sites in the UK and China}

The built heritage attractions in this research are defined as inherited sites which can be promoted as heritage tourism products. The numbers of built heritage attractions in both the UK and China are huge; it would be challenging to ask all attractions to participate in this research. Furthermore, if selected, the attractions by population may ignore their natures of heritage. Therefore, to ensure that the survey results can represent a wide range of built heritage attractions, built heritage attractions in the UK and China were divided into different categories according to their original purpose; three or four attractions were selected to represent each category. In China, the categories comprised Museum, Historic House, Religious, Garden and Park, Ancient Town, Mountain and Mausoleum Combined Heritage. In the UK, the categories comprised Historic House, Religious, Garden and Park, Castle and Museum. The responding attractions included four of the five UK built heritage attraction categories; none of the attractions in the museum category participated in the survey. The responding attractions included six of the seven Chinese built heritage attraction categories; none of the mausoleum combined heritage category participated in the survey.

\subsection{A questionnaire Approach}

A survey questionnaire was designed based on the key factors of sustainable development for built heritage attractions (Appendix A.1). The questionnaire was divided into three sections: (i) basic profile information on the attractions; (ii) the importance of the key indicators of sustainability; and (iii) planning and management for sustainable heritage attractions. Section (i) was used to collect background information on the attractions surveyed, which included the attractions' tourist numbers, human resources management, contacts and organizational structure. Section (ii) aimed to examine the relative importance of a set of built heritage sustainability indicators (Table 1) for heritage attraction site managers. This section requested that participants mark the importance of the indicators from the most to the least important in terms of five levels: extremely important, important, moderately important, of little importance and unimportant. Section (iii) aimed to identify the participants' views of planning and management for built heritage attractions. Open questions were used to ask participants to comment on the sustainable indicators and the importance of sustainability appraisal for built heritage attractions. The research targeted the management team of the attractions listed.

The Google Documents website was used to collect data for attractions which responded online, and field visits were arranged to a few attractions to stimulate attraction managers in person in both counties to participate in the research. The survey provided a very useful management perspective and the context of sustainability implementation in practice for built heritage attractions.

Questionnaire survey aimed to examine the relative importance of a set of built heritage sustainability indicators for heritage attraction site managers for assigning weights to each indicator to reflect its importance. Questionnaire survey requested that participants mark the importance of the indicators from the most to the least important in terms of five levels: extremely important, important, moderately important, of little importance and unimportant. For instance, as all the sub-indicators have five degrees and can represent scores from 1 to 5 (Unimportant $=1$; of little importance $=2$; Moderately Important $=3$; Important $=4$; and Extremely Important $=5$ ). Then, presume a participant marks one sub-indicator A as Unimportant by giving it a weight of 1 , then marks another sub-indicator B as "Moderately important" with a score of 3 . The weighting approach was used for comparison; the sum of each weight is normalized by division of each sum with the total sums. Take the indicator of providing local employment in China for example: Participants weighting this indicator as extremely important accounting for $30 \%$ of all participants, Participants weighting this indicator as the important accounting for $30 \%$ of all participants, Participants weighting this indicator as the moderately important accounting for $20 \%$ of all participants, Participants weighting this indicator as the Of little importance accounting for $20 \%$ of all participants and no participants weighted this indicator Unimportant. Section B was analysed by comparing the value of score in both countries. 
Table 1. Sustainability indicators for built heritage attractions management used in the questionnaire research.

\begin{tabular}{|c|c|c|c|}
\hline Dimensions & Indicators & Reasons of Selection & $\begin{array}{l}\text { Current Qualitative and/or Quantitative } \\
\text { Measurement in the UK or China }\end{array}$ \\
\hline \multirow{3}{*}{ Economic } & Providing local employment & $\begin{array}{l}\text { Having qualified employees to provide services and to operate the facilities helps the attraction to achieve sustainable } \\
\text { development. Meanwhile, one of the main benefits of a built heritage attraction is that it can provide employment, promote } \\
\text { prosperity and transform the economic typology of the surrounding communities (Wall and Mathieson, 2006; Mason, 2009). }\end{array}$ & $\begin{array}{l}\text { Local employment rates } \\
\text { Employment statistics } \\
\text { Participation rate }\end{array}$ \\
\hline & $\begin{array}{l}\text { Growth in annual gross } \\
\text { income of attraction }\end{array}$ & $\begin{array}{l}\text { Heritage tends to be regarded as more valuable when it becomes a source of revenue. The utilization of heritage has shifted } \\
\text { from a cultural and aesthetic appreciation to a way of increasing income. Income cannot directly improve sustainability, but } \\
\text { greater income may mean attractions have more resources to invest in sustainability (McKercher and Ho, 2006). }\end{array}$ & $\begin{array}{l}\text { Annual Gross Income } \\
\text { Annual Net Income }\end{array}$ \\
\hline & $\begin{array}{l}\text { External funding support for } \\
\text { the built heritage attraction }\end{array}$ & The external funds may be used as an index to measure support from others sources rather than tourism incomes. & Amount of Funding \\
\hline \multirow{4}{*}{ Environmental } & Efficient amenities & $\begin{array}{l}\text { The green initiatives and new technology enable water and energy use to become more efficient, to promote a greener } \\
\text { management model. }\end{array}$ & $\begin{array}{l}\text { Quality of Facilities } \\
\text { Greenspace coverage rate } \\
\text { Quality of Local food systems }\end{array}$ \\
\hline & $\begin{array}{l}\text { Waste and pollution } \\
\text { management }\end{array}$ & $\begin{array}{l}\text { Waste management includes different factors to reduce negative environmental impacts as much as possible. Solid waste is } \\
\text { the main pollution source to the environment and of the destination; a good environment will meet the tourists' sanitary } \\
\text { demands and attract more tourists. }\end{array}$ & $\begin{array}{l}\text { Recycling rate } \\
\text { Landfilling rate } \\
\text { Incineration rate } \\
\text { Data sources and availability }\end{array}$ \\
\hline & $\begin{array}{l}\text { Possessing an environmental } \\
\text { management system }\end{array}$ & $\begin{array}{l}\text { Environmental management provides a systematic, planned approach to the management of environmental issues at a built } \\
\text { heritage attraction and should be adopted as part of the overall operations. }\end{array}$ & $\begin{array}{l}\text { Energy consumption } \\
\text { Quality of Land-take for settlements and } \\
\text { transport infrastructure }\end{array}$ \\
\hline & $\begin{array}{l}\text { Historic buildings' } \\
\text { conservation and } \\
\text { preservation }\end{array}$ & $\begin{array}{l}\text { The conservation and preservation would maintain and increase the value of historic buildings by keeping their original } \\
\text { architectural elements and built forms. Integrating tourism and conservation at a public authority or government level is } \\
\text { becoming a significant issue for stakeholders. }\end{array}$ & $\begin{array}{l}\text { Quality of Authenticity } \\
\text { Quality of Integrity } \\
\text { Quality of Conservation and preservation }\end{array}$ \\
\hline \multirow{3}{*}{ Social } & $\begin{array}{l}\text { Support from attraction to } \\
\text { local communities }\end{array}$ & $\begin{array}{l}\text { Residents play an important role in sustainable development; the destinations and attractions draw tourists who can benefit } \\
\text { the residents. Most of the local residents react to tourist activities with positive attitudes. }\end{array}$ & $\begin{array}{l}\text { Communities participation } \\
\text { rate and approaches }\end{array}$ \\
\hline & $\begin{array}{l}\text { Local residents' satisfaction } \\
\text { with the operation of the } \\
\text { attraction }\end{array}$ & $\begin{array}{l}\text { Mason (2009) suggested that the inclusion of local residents in the activities engaged in are the key influences on } \\
\text { social-culture impacts. Assessing and measuring social-cultural impacts is not straightforward, and most research has relied } \\
\text { on the attitudes of locals and tourists. }\end{array}$ & Local residents' satisfaction rate \\
\hline & $\begin{array}{l}\text { Traffic congestion during } \\
\text { peak tourism periods }\end{array}$ & Traffic congestion during peak tourism would lead the local communities complaining about the adverse tourism impacts. & $\begin{array}{l}\text { Traffic congestion time during peak } \\
\text { tourism periods }\end{array}$ \\
\hline \multirow{4}{*}{ Governance } & $\begin{array}{l}\text { Involvement of key } \\
\text { stakeholders }\end{array}$ & $\begin{array}{l}\text { To establish a win-win system for heritage tourism and sustainable development, the views of all stakeholders should be } \\
\text { considered and as much as possible catered for. Encouraging their participation will reduce resistance to } \\
\text { further development. }\end{array}$ & $\begin{array}{l}\text { Stakeholders participation } \\
\text { rate and approaches }\end{array}$ \\
\hline & $\begin{array}{l}\text { Producing sustainability } \\
\text { documents }\end{array}$ & $\begin{array}{l}\text { Sustainability documents would provide an appropriate heritage planning strategy to facilitate the heritage } \\
\text { tourism management. }\end{array}$ & Quality of sustainability documents \\
\hline & Urban planning & $\begin{array}{l}\text { Planning is a vital tool in regulating heritage conservation and tourism development, integrating the commercial value of } \\
\text { built heritage attractions in proactive ways. When planning decisions are made they should be based both on heritage } \\
\text { conservation and tourism development dimensions. }\end{array}$ & $\begin{array}{l}\text { green cover ratio; lawn cover ratio; tree cover } \\
\text { ratio; street cover ratio; building cover ratio } \\
\text { building volume density } \\
\text { Quality of planning policy formulation and } \\
\text { implementation }\end{array}$ \\
\hline & $\begin{array}{l}\text { Legal basis for heritage } \\
\text { protection }\end{array}$ & All the heritage development should ensure full regulatory compliance as the baseline of all actions. & Quality of legal basis for heritage protection \\
\hline
\end{tabular}




\subsection{Response and Non-Response of the Questionnaire Survey}

Across both China and the UK, 93 attractions were invited to participate and 36 responded before the deadline. The responding attractions included four of the five UK built heritage attraction categories; none of the attractions in the museum category participated in the survey; the categories of historic house and castle had more responding attractions than the other categories (Table 2). In China, the responding attractions included six of the seven Chinese built heritage attraction categories; none of the mausoleum combined heritage category participated in the survey and the categories of historic house, garden and parks and ancient towns had more responding attractions than other categories (Table 3). The Chinese response rate was high at 78\%, while the UK response rate was much lower at $23 \%$. The Chinese response rate benefitted particularly from the use of tourism networking and personal contacts, but some attractions still did not fully complete the questionnaire because environmental issues remain sensitive. In the UK, a number of announcements were made to generate a sample of similar size to that obtained for China.

Table 2. Surveyed responding attractions in the UK.

\begin{tabular}{cccc}
\hline Attractions & Location & Category & Annual Visitors (2013) \\
\hline Royal Botanic Gardens, Kew & London & Garden and Park & $1,400,000$ \\
Cotswold Wildlife Park & Oxfordshire & Garden and Park & 300,000 \\
Castleton House and Garden & Oxfordshire & Garden and Park & 36,000 \\
Edinburgh Castle & Edinburgh & Castle & $1,230,177$ \\
Stirling Castle & Stirling & Castle & 401,843 \\
Highclere Castle & West Berkshire & Castle & 300,000 \\
Oxford Castle Unlocked & Oxfordshire & Castle & 71,000 \\
Broughton Castle & Oxfordshire & Castle & 12,000 \\
Hampton Court Palace & London & Historic House & 524,000 \\
Kensington Palace & London & Historic House & 404,000 \\
Hughenden Manor & Buckinghamshire & Historic House & 93,500 \\
Greys Court & Oxfordshire & Historic House & 88,000 \\
Dennis Severs House & London & Historic House & 10,000 \\
St Paul's Cathedral & London & Religious & 745,838 \\
University Church Oxford & Oxfordshire & Religious & 300,000 \\
\hline
\end{tabular}

Source: All data were from the questionnaire survey.

Table 3. Surveyed responding attractions in China.

\begin{tabular}{cccc}
\hline Attractions & Location & Category & Annual Visitors (2013) \\
\hline West Lake World Heritage & Zhejiang Province & Garden and Park & $28,508,100$ \\
Cui Lake & Yunnan Province & Garden and Park & $12,000,000$ \\
Kansas National Parks & Xinjiang Region & Garden and Park & $1,680,000$ \\
Gezi Wo Park & Hebei Province & Garden and Park & 939,000 \\
Heaven Lake of Tian Shan & Xinjiang Region & Garden and Park & 899,200 \\
Fenghua Xikou & Zhejiang Province & Ancient Town & $5,437,000$ \\
Hong Ancient Village & Anhui Province & Ancient Town & 350,000 \\
GuanDu & Yunnan Province & Ancient Town & 200,000 \\
Hui Yuan & Xinjiang Region & Ancient Town & 80,000 \\
Jiang Keer & Xinjiang Region & Ancient Town & 25,000 \\
Minggu City & Shangdong Province & Historic House & $3,000,000$ \\
Shanhai Pass & Hebei Province & Historic House & $2,236,172$ \\
Three Gorges & Hubei Province & Historic House & $1,500,000$ \\
Wang's Grand Courtyard & Hebei Province & Historic House & 205,000 \\
Jie Yang & Hebei Province & Historic House & 200,000 \\
Lama Temple & Beijing Municipality & Religious & 340,000 \\
Mountain Zu & Hebei Province & Mountain & 118,000 \\
Mountain Fengming & Hubei Province & Mountain & 110,000 \\
Mountain Changshou & Hebei Province & Mountain & 105,000 \\
Museum of Lizexu & Xinjiang Region & Museum & 100,000 \\
Museum of Han Princess & Xinjiang Region & Museum & 63,000 \\
\hline
\end{tabular}

Source: Sll data were from the questionnaire survey. 


\subsection{Four Main Case Studies}

The case studies were selected to allow the researcher to study attractions, which have some features or processes that are of interest [46]. Case study approach was used to further investigate the sustainability of built heritage attractions in the UK and China. The set of indicators was revised after questionnaire survey for ensuring measuring sustainability performance more reliable (Figure 1). Chastleton House $(\mathrm{CH})$ and Oxford Castle Heritage Site (OCHS, which includes the Oxford Castle Quarter and Oxford Castle Unlocked Attraction) in the UK were selected, while Mountain Jieshi (MJ, which includes the Mountain Jieshi Attraction and the Water Rock Temple) and Shanhai Pass, the Great Wall of China (SPGWC) in China were selected (Appendix ??).

Existing documents related to the surveyed attractions were reviewed. Each case invited a group of stakeholders (attraction managers, third parties, residents and visitors) to participate. Taking the case of Oxford Castle Heritage Site for example, this research interviewed a planning officer of Oxford Country Council involved in the Oxford Castle Heritage Regeneration Project, two staff working at Oxford Preservation Organization, a member of management team of Oxford Castle Quarter and a member of management team of Oxford Castle Unlocked Attraction, and a resident of Oxford. Fifty visitors to Oxford Castle were asked to fill a questionnaire on their perception of heritage tourism management of the site. An in-depth interview approach involving 19 stakeholders of four cases was used to reduce assessment bias (Appendix A.2).

The data were collected and analysed based on revised third set of indicators in four dimensions. The qualitative data of four case studies was analysed using an inductive method, seeking similar themes in the respondents' opinions. Qualitative data of documentary sources and interview transcripts and were analysed to identity the both common issues and variations from case studies. For example, to evaluate the indicator of planning in each case study, this research asked the opinions on stakeholders who involved the planning on the planning policy formulating or implementation, and then compared case studies findings between attractions in both countries. All the developed sub-indicators were used to compare sustainability value by the qualitative data collected from above research.

\subsection{Verification and Validation}

With the purpose of ensuring both the reliability and the validity of the data, three strategies were used for verification: checking for methodological coherence [47], checking by participants [47] and triangulation [48]. Methodological coherence was checked by internal congruence through the connected relationship between the aims, objectives, sampling strategies, research strategies, data collection methods, data analysis, coding techniques and other research methods used. The checking by participants process included email verification with 15 participants who are heritage professionals in industry and academia, including academic experts in heritage management and experienced heritage attraction managers; some of them were involved in this project during 2012-2016. The preliminary findings of the research with other professionals were triangulated during the email validation process. After writing up the first draft of the thesis, a summary report was produced and distributed to individuals who participated in this research for validation.

Verification and validation emails were sent to a group of participants presenting the final findings to enquire their opinions. This step was utilized to examine the sustainability indicators used for built heritage attractions on sustainability of heritage management both in China and the UK. A summary of research and a set of validation questionnaire were sent to them for collecting their comments after they reviewed the summary of research, the theme of questions includes the sustainability appraisal approach of built heritage attractions, strengths and weaknesses, set of indicators and other comments or suggestions. 
Five validation participants responded and highlighted the merits and weaknesses of the research approach and research findings. The participants indicated that this approach is relatively comprehensive, practical and appropriate to apply to other attractions. However, concerns were raised in the areas of risk aversion, applying the methodology to more case studies, stakeholders and continuing improvements.

\section{Research Findings from the Survey Responses}

The sustainability of built heritage attractions in this research is defined as the idea that a built heritage attraction should consider long term development and effective conservation at the same time, considering the interests of the attraction management team, visitors and other stakeholders. Sustainability performance should be assessed in terms of economic, social, environmental and governance dimensions by using appropriate approaches. The research findings indicated the sustainability of built heritage attractions and several important variations in response to the relative importance of the key sustainable indicators.

This section compares research findings from three perspectives: the current situations in both countries in relation to the relative importance of key sustainability indicators; as assessed by built heritage attraction managers in both countries (Table 4); and the qualitative findings of case studies. These variations in responses are considered in terms of differences between the UK and China. Tables 5 and 6 show the ranking of all indicators in each country.

This research considered the applicable of indicators after ranking tenth in both countries. Therefore, the indicators of Urban planning, External funding support for the built heritage attraction, Possessing Environmental Management System, Traffic congestion on peak tourism periods, Involvement of key stakeholders and Support from attraction to local communities were deleted or revised when applying the second set of indicators. 
Table 4. Indicator importance weighting results from attraction managers.

\begin{tabular}{|c|c|c|c|c|c|c|c|}
\hline \multicolumn{8}{|c|}{ Economic Dimension } \\
\hline Indicators & Country & $\begin{array}{l}\text { Extremely } \\
\text { Important }\end{array}$ & Important & $\begin{array}{c}\text { Moderately } \\
\text { Important }\end{array}$ & $\begin{array}{c}\text { Of Little } \\
\text { Importance }\end{array}$ & Unimportant & $\begin{array}{l}\text { Ranking in } \\
\text { Each Country }\end{array}$ \\
\hline \multirow{2}{*}{ Providing local employment } & $i(U K)$ & $40 \%$ & $47 \%$ & $13 \%$ & $0 \%$ & $0 \%$ & 10 \\
\hline & ii (China) & $30 \%$ & $30 \%$ & $20 \%$ & $20 \%$ & $0 \%$ & 10 \\
\hline \multirow{2}{*}{ Growth in annual gross income of attraction } & i & $57 \%$ & $36 \%$ & $7 \%$ & $0 \%$ & $0 \%$ & 6 \\
\hline & ii & $43 \%$ & $43 \%$ & $10 \%$ & $5 \%$ & $0 \%$ & 7 \\
\hline \multirow{2}{*}{ External funding support for the built heritage attraction } & $i$ & $31 \%$ & $38 \%$ & $23 \%$ & $0 \%$ & $8 \%$ & 12 \\
\hline & ii & $38 \%$ & $38 \%$ & $24 \%$ & $0 \%$ & $0 \%$ & 8 \\
\hline \multicolumn{8}{|c|}{ Environmental Dimension } \\
\hline \multirow{2}{*}{ Efficient water and energy systems } & $i$ & $67 \%$ & $20 \%$ & $13 \%$ & $0 \%$ & $0 \%$ & 2 \\
\hline & $i i$ & $57 \%$ & $29 \%$ & $14 \%$ & $0 \%$ & $0 \%$ & 4 \\
\hline \multirow{2}{*}{ Waste and pollution management preventing } & $i$ & $67 \%$ & $13 \%$ & $20 \%$ & $0 \%$ & $0 \%$ & 3 \\
\hline & $i i$ & $62 \%$ & $29 \%$ & $10 \%$ & $0 \%$ & $0 \%$ & 2 \\
\hline \multirow{2}{*}{ Possessing Environmental Management System } & $i$ & $15 \%$ & $23 \%$ & $46 \%$ & $8 \%$ & $8 \%$ & 13 \\
\hline & ii & $33 \%$ & $33 \%$ & $29 \%$ & $5 \%$ & $0 \%$ & 9 \\
\hline \multirow{2}{*}{ Historic buildings conservation and preservation } & $i$ & $93 \%$ & $0 \%$ & $0 \%$ & $7 \%$ & $0 \%$ & 1 \\
\hline & ii & $71 \%$ & $29 \%$ & $0 \%$ & $0 \%$ & $0 \%$ & 1 \\
\hline \multicolumn{8}{|c|}{ Social Dimension } \\
\hline \multirow{2}{*}{ Support from attraction to local communities } & $i$ & $40 \%$ & $60 \%$ & $0 \%$ & $0 \%$ & $0 \%$ & 9 \\
\hline & ii & $33 \%$ & $48 \%$ & $14 \%$ & $5 \%$ & $0 \%$ & 12 \\
\hline \multirow{2}{*}{ Local residents' satisfaction with the operation of the attraction } & $i$ & $60 \%$ & $20 \%$ & $20 \%$ & $0 \%$ & $0 \%$ & 4 \\
\hline & ii & $38 \%$ & $29 \%$ & $33 \%$ & $0 \%$ & $0 \%$ & 5 \\
\hline \multirow{2}{*}{ Traffic congestion on peak tourism periods } & $i$ & $23 \%$ & $31 \%$ & $38 \%$ & $8 \%$ & $0 \%$ & 14 \\
\hline & $i i$ & $62 \%$ & $19 \%$ & $14 \%$ & $5 \%$ & $0 \%$ & 3 \\
\hline \multicolumn{8}{|c|}{ Governance Dimension } \\
\hline \multirow{2}{*}{ Legal basis for heritage protection } & $i$ & $47 \%$ & $33 \%$ & $20 \%$ & $0 \%$ & $0 \%$ & 8 \\
\hline & ii & $43 \%$ & $43 \%$ & $14 \%$ & $0 \%$ & $0 \%$ & 6 \\
\hline \multirow{2}{*}{ Involvement of key stakeholders } & $i$ & $57 \%$ & $21 \%$ & $14 \%$ & $7 \%$ & $0 \%$ & 7 \\
\hline & ii & $29 \%$ & $29 \%$ & $38 \%$ & $5 \%$ & $0 \%$ & 11 \\
\hline \multirow{2}{*}{ Producing sustainability documents } & $i$ & $60 \%$ & $13 \%$ & $13 \%$ & $0 \%$ & $13 \%$ & 5 \\
\hline & $i i$ & $29 \%$ & $43 \%$ & $24 \%$ & $5 \%$ & $0 \%$ & 14 \\
\hline \multirow{2}{*}{ Urban planning } & $i$ & $23 \%$ & $46 \%$ & $23 \%$ & $8 \%$ & $0 \%$ & 11 \\
\hline & $i i$ & $29 \%$ & $43 \%$ & $29 \%$ & $0 \%$ & $0 \%$ & 13 \\
\hline
\end{tabular}

Note. $i=\mathrm{UK} ; i i=$ China. 
Table 5. Importance of Indicators Ranking in UK Indicators.

\begin{tabular}{|c|c|c|c|c|c|c|}
\hline Indicators & $\begin{array}{l}\text { Extremely } \\
\text { Important }\end{array}$ & Important & $\begin{array}{l}\text { Moderately } \\
\text { Important }\end{array}$ & $\begin{array}{l}\text { Of Little } \\
\text { Importance }\end{array}$ & Unimportant & Ranking \\
\hline $\begin{array}{l}\text { Historic buildings conservation } \\
\text { and preservation }\end{array}$ & $93 \%$ & $0 \%$ & $0 \%$ & $7 \%$ & $0 \%$ & 1 \\
\hline $\begin{array}{l}\text { Efficient water and } \\
\text { energy systems }\end{array}$ & $67 \%$ & $20 \%$ & $13 \%$ & $0 \%$ & $0 \%$ & 2 \\
\hline $\begin{array}{l}\text { Local residents' satisfaction with } \\
\text { the operation of the attraction }\end{array}$ & $60 \%$ & $20 \%$ & $20 \%$ & $0 \%$ & $0 \%$ & 4 \\
\hline $\begin{array}{l}\text { Producing sustainability } \\
\text { documents }\end{array}$ & $60 \%$ & $13 \%$ & $13 \%$ & $0 \%$ & $13 \%$ & 5 \\
\hline $\begin{array}{l}\text { Legal basis for heritage } \\
\text { protection }\end{array}$ & $47 \%$ & $33 \%$ & $20 \%$ & $0 \%$ & $0 \%$ & 8 \\
\hline $\begin{array}{l}\text { Support from attraction to local } \\
\text { communities }\end{array}$ & $40 \%$ & $60 \%$ & $0 \%$ & $0 \%$ & $0 \%$ & 9 \\
\hline Providing local employment & $40 \%$ & $47 \%$ & $13 \%$ & $0 \%$ & $0 \%$ & 10 \\
\hline Urban planning & $23 \%$ & $46 \%$ & $23 \%$ & $8 \%$ & $0 \%$ & 11 \\
\hline $\begin{array}{l}\text { External funding support for the } \\
\text { built heritage attraction }\end{array}$ & $31 \%$ & $38 \%$ & $23 \%$ & $0 \%$ & $8 \%$ & 12 \\
\hline $\begin{array}{l}\text { Possessing Environmental } \\
\text { Management System }\end{array}$ & $15 \%$ & $23 \%$ & $46 \%$ & $8 \%$ & $8 \%$ & 13 \\
\hline
\end{tabular}

Table 6. Importance of Indicators Ranking in China.

\begin{tabular}{|c|c|c|c|c|c|c|}
\hline Indicators & $\begin{array}{l}\text { Extremely } \\
\text { Important }\end{array}$ & Important & $\begin{array}{l}\text { Moderately } \\
\text { Important }\end{array}$ & $\begin{array}{c}\text { Of Little } \\
\text { Importance }\end{array}$ & Unimportant & Ranking \\
\hline $\begin{array}{l}\text { Historic buildings conservation } \\
\text { and preservation }\end{array}$ & $71 \%$ & $29 \%$ & $0 \%$ & $0 \%$ & $0 \%$ & 1 \\
\hline $\begin{array}{c}\text { Waste and pollution } \\
\text { management preventing }\end{array}$ & $62 \%$ & $29 \%$ & $10 \%$ & $0 \%$ & $0 \%$ & 2 \\
\hline $\begin{array}{l}\text { Traffic congestion on peak } \\
\text { tourism periods }\end{array}$ & $62 \%$ & $19 \%$ & $14 \%$ & $5 \%$ & $0 \%$ & 3 \\
\hline $\begin{array}{l}\text { Efficient water and energy } \\
\text { systems }\end{array}$ & $57 \%$ & $29 \%$ & $14 \%$ & $0 \%$ & $0 \%$ & 4 \\
\hline $\begin{array}{l}\text { Local residents' satisfaction with } \\
\text { the operation of the attraction }\end{array}$ & $38 \%$ & $29 \%$ & $33 \%$ & $0 \%$ & $0 \%$ & 5 \\
\hline $\begin{array}{l}\text { Legal basis for heritage } \\
\text { protection }\end{array}$ & $43 \%$ & $43 \%$ & $14 \%$ & $0 \%$ & $0 \%$ & 6 \\
\hline $\begin{array}{c}\text { Growth in annual gross income } \\
\text { of attraction }\end{array}$ & $43 \%$ & $43 \%$ & $10 \%$ & $5 \%$ & $0 \%$ & 7 \\
\hline $\begin{array}{l}\text { External funding support for the } \\
\text { built heritage attraction }\end{array}$ & $38 \%$ & $38 \%$ & $24 \%$ & $0 \%$ & $0 \%$ & 8 \\
\hline $\begin{array}{l}\text { Possessing Environmental } \\
\text { Management System }\end{array}$ & $33 \%$ & $33 \%$ & $29 \%$ & $5 \%$ & $0 \%$ & 9 \\
\hline Providing local employment & $30 \%$ & $30 \%$ & $20 \%$ & $20 \%$ & $0 \%$ & 10 \\
\hline Involvement of key stakeholders & $29 \%$ & $29 \%$ & $38 \%$ & $5 \%$ & $0 \%$ & 11 \\
\hline $\begin{array}{l}\text { Support from attraction to local } \\
\text { communities }\end{array}$ & $33 \%$ & $48 \%$ & $14 \%$ & $5 \%$ & $0 \%$ & 12 \\
\hline Urban planning & $29 \%$ & $43 \%$ & $29 \%$ & $0 \%$ & $0 \%$ & 13 \\
\hline $\begin{array}{c}\text { Producing sustainability } \\
\text { documents }\end{array}$ & $29 \%$ & $43 \%$ & $24 \%$ & $5 \%$ & $0 \%$ & 14 \\
\hline
\end{tabular}




\subsection{Economic Dimension}

\subsubsection{Current Situations}

For current situations in both countries, heritage makes a vital contribution to the UK economy and China. In the UK, heritage tourism generated $£ 16.4$ billion in spending by domestic and international visitors; Repair and maintenance of historic buildings directly generated $£ 9.6$ billion in construction sector output; and 278,000 people are employed in heritage [49]. Heritage tourism plays a vital role in China: more than $60 \%$ of the leading tourism attractions in China are heritage attractions [50].

\subsubsection{Questionnaire Survey}

Within the questionnaire survey, attractions in the UK tend to emphasize the importance of local employment and growth in annual gross income more strongly, while attractions in China emphasize external funding. This may be due to the different social construction and legislation systems in the two countries. Attractions in the UK tend to show a stronger willingness to take on more social responsibilities and make more social contribution to local areas. Attractions in China have more external funding because attractions in China are owned by the government.

\subsubsection{Case Studies}

Within the case studies, attractions in China received higher attentions on permanent employment and local staff percentage than attractions in the UK. The attractions in China are under the management of local government, which is more closely associated with providing stable employment compared to the attractions in the UK. This may be illustrated by two factors. Firstly, the surveyed attractions in China belong to the local government, so some of these positions are very stable because they are civil servants. Many people wish to apply for these positions and settle down for a steady position. Secondly, the Chinese attractions are happy to recruit more local employees to reduce the turnover rate. Although all attractions have similar scores on the sub-indicators of net profit/income of an attraction divided by the attraction's employee numbers, attractions in China have a stronger tendency and desire to make a profit. During the interviews, the attractions in China were more eager to increase their growth and financial payment ability. In interviews with the management teams of the attractions in China, all agreed that funding is the most important factor, as there would be no development without funds. However, in interviews with the management teams of the attractions in the UK, fewer concerns were expressed about funding; they believe it is important, but is not the most significant issue. This may also be because of their funding bodies. $\mathrm{CH}$ belongs to the NT (National Trust), so they receive funds from the NT funding pool. The Oxford Castle Unlocked Attraction has been developed by the other private company, and they receive funds from many sources, for example, National lottery funds, English Heritage, commercial units and so on. Nevertheless, the attractions in China also receive funds from the government, but most of the time, these are less than expected. Thus, they could increase their income by using tourist resources for their development. There were few differences on tourism carrying capacity and tourist number efficiency between the two countries.

\subsection{Environmental Dimension}

\subsubsection{Current Situations}

The basic difference between England and China is the attitude to sustainable development; England highlights the importance of sustainable development and involves conservation policies and methods, especially in the new National Planning Policy Framework (NPPF), while China has not yet realized the importance of sustainable development in heritage conservation and no planning and conservation regulations require sustainable development (Table 7). 
Table 7. Comparison of Heritage Conservation Systems in England and China.

\begin{tabular}{cll}
\hline Scope & \multicolumn{1}{c}{ England } & \multicolumn{1}{c}{ China } \\
\hline Methods & $\begin{array}{l}\text { Scheduled monuments, listed buildings, local designation, } \\
\text { registered battlefields, registered park and gardens. }\end{array}$ & $\begin{array}{l}\text { Heritage ruins, Historic Tombs, Historic } \\
\text { buildings, grotto ruins, temples, stone } \\
\text { inscriptions, wall paintings and heritage sites. }\end{array}$ \\
\hline Planning Principle & $\begin{array}{l}\text { The historic environment and its heritage assets should be } \\
\text { conserved and enjoyed for the quality of life they bring to } \\
\text { this and future generations. }\end{array}$ & $\begin{array}{l}\text { Lists, schedules, inventories and records. } \\
\text { consider and include the requirements and } \\
\text { practical situation of heritage conservation at } \\
\text { all levels of government. }\end{array}$ \\
\hline $\begin{array}{c}\text { The Executive } \\
\text { Agencies }\end{array}$ & $\begin{array}{l}\text { Allow public involvement, but government takes the main } \\
\text { responsibility, such as the Department for Culture, Media } \\
\text { and Sport, Communities and Local Government, English } \\
\text { Heritage and Local Planning Authority. }\end{array}$ & $\begin{array}{l}\text { Little public involvement; the government } \\
\text { takes the main responsibility, such as the State } \\
\text { Administration of Cultural Heritage, Ministry } \\
\text { of Housing and Urban-Rural Development, } \\
\text { Chinese Commission for the International } \\
\text { Council on Monuments and Sites. }\end{array}$ \\
\hline Financial Sources
\end{tabular}

Although the scope and methods of heritage conservation between England and China are similar, the political systems between the two countries differ in relation to executive agencies and financial sources. The government takes the majority of the responsibility for managing heritage conservation and provides financial support in China; in England, there is a greater tendency to use a wider range of approaches by involving non-governmental organizations, such as the HLF and National Trust.

Although the heritage conservation of England has been supported by laws and policies, the conservation actions and management of conservation areas have been questioned for insufficiently dealing with the extensive and complex scope of heritage. This researcher holds the opinion that, as a result of a lack of fixed heritage conservation rules, the current system of heritage conservation leads to confusion in management and poor compromises for the public.

On the other hand, as a unitary state, the different levels of government in China take more responsibility for heritage conservation, and few private and non-government organizations (NGOs) are allowed to participate in heritage management. Meanwhile, although laws and regulations have been launched for heritage protection, the practical implementation of these is still sometimes outside of supervision and the public has not been sufficiently involved in the heritage conservation process.

The trend is for the built heritage estate to grow both in England and in China. While the trend in England has been stated earlier and is stable, China has witnessed a fast growth in its built heritage estate in recent years to meet the demand of the tourism market and heritage conservation.

\subsubsection{Questionnaire Survey}

Within the questionnaire survey, there are barely any differences on the perceptions of the importance of efficient water and energy systems between the countries. The attractions in China tend to have a stronger view on possessing environmental management systems, while attractions in the UK tend to emphasize the importance of waste and pollution management and the conservation and preservation of historic buildings more strongly. Attractions in China tend to have a stronger view on environmental documentation management, while attractions in the UK tend to have a stronger view on environmental practices. The attractions' management systems vary between the two countries. Tourist authorities in China tend to intervene and regulate their attractions more, while the UK appears to have less intervention. Furthermore, attractions in the UK tend to have a more mature system and more experience in environmental management than those in China. 


\subsubsection{Case Studies}

Within the case studies, attractions in both countries have similar sub-indicators attention on their environmental management systems; water, electrical and gas consumption trends and waste recycling rate. However, attractions in the UK tend to have a stronger performance on environmental protection and a larger environmental scope than attractions in China. Attractions in the UK received higher scores of importance in this area; this may be because they established a high standard of environmental management system after different stakeholders participated. Although not all attractions have established a specific environmental management system, all of them include environmental management in their management. The scope of environmental management systems in the UK attractions is wider than in attractions in China. The environmental management system in the UK may concern management, recycling, the physical environment, attraction cleanliness and energy efficiency, while, in China, attractions tend to focus on attraction cleanliness and recycling, and recycling is normally managed by local government. For example, $\mathrm{CH}$ established the Environment Management System Action Plan 2014 and the NT Environmental Standard for Parks and Gardens Guidance 2012 for identifying a range of environmental management problems and implementing appropriate actions. OCHS encompasses sustainable commercial use as well as a full interpretation of the site's history and heritage. A series of actions were taken to ensure sustainability techniques were employed throughout the construction and the site aims to reduce private car use by encouraging the use of public transportation. When referring to environmental management, MJ and SPGWC focus on trying to do well on attraction cleaning and waste management. Attractions in both countries are using both recyclable and non-recyclable bins, but these bins in China are not always well used due to the management ability. Furthermore, China has a different waste recycling management system and classification system from in the UK. In China, local environmental authorities take away all the waste after collection from the attractions. There are various records kept on Chinese urban waste recycling rates, and at least $40 \%$ of general waste has been recycled before waste is sent to landfill [54].

The funds come from different conservation systems in the UK and China. Built heritage attractions in the UK have a tendency to have various funding bodies and more investment in heritage conservation than in China; the larger attractions tend to have more ability to secure heritage funds than small attractions. The investment in conservation, preservation and restoration may be managed and funded by different organizations in both countries. The UK has a tendency to have various funding bodies and more investment in heritage conservation than China. For example, conservation funds in the UK may come from English Heritage, Heritage Lottery, private investors, local government, heritage conservation NGOs and donations from the public. However, most heritage conservation funds come from government and private commercial developers in China; whilst some funds may come from tourism income and investment, this is very limited when compared to the total heritage investment.

\subsection{Social Dimension}

\subsubsection{Current Situations}

Both the UK and China are facing similar social issues of heritage tourism. Heritage-led regeneration projects developed earlier in the UK than in China; an increasing number of Chinese developers have been looking for heritage-led regeneration opportunities in China recently. Two important differences between them are noted here.

The conservation and maintenance of built heritage sites: Built heritage sites in the UK have a tendency to keep their original materials and fabrics as much as possible; the repair and maintenance cost for heritage projects are normally very high and time-consuming. In China, a significant number of built heritage sites were destroyed after the 1950s; however, recently built heritage sites have been treated as valuable treasures for booming local economies. In China, the repair and maintenance of heritage projects are normally completed very quickly, but primary attention is often paid to 
the appearance of built heritage; the authenticity was doubtful in many cases as modern building technology and modern materials were used to rebuild heritage sites.

In the UK, stakeholders' participation is encouraged for heritage-led regeneration projects. For almost all heritage sites the local community are consulted and involved as are a wide range of stakeholders before/during the conservation project. In China, since most heritage sites belong to the local government, the development of heritage involves a limited scope of stakeholders, mainly government officers, the developers and experts. Representatives of the local community may be consulted on certain projects, but their opinions and interests are largely ignored by decision makers.

\subsubsection{Questionnaire Survey}

Within the of questionnaire survey, both countries value indicators of support for the attractions within local communities, although UK attractions tend to place more emphasis on the value of support. Attractions in China tend to have a stronger view on traffic congestion during peak tourism periods. This difference may be because attractions in China are still in the development stage and so they need to deal with an increasing number of tourists visiting by vehicle, while attractions in the UK have developed a relatively mature management system after their many years of operation.

\subsubsection{Case Studies}

Within the case studies, attractions in both countries have similar attention on annual concession percentage; the attitudes towards the attractions from third parties and visitors. However, attractions in China tend to have a higher interview performance on sub-indicators of local stakeholders' involvement. The interview performance cannot always represent the status of development, and attractions in the UK have a more transparent policy than attractions in China and involve the local community more when decisions are made. Attractions in China have higher interview performance on overall stakeholder involvement because they are government-owned, attractions in the UK involve a wider range of stakeholders when dealing with a plan than attractions in China. Taking Oxford Castle Regeneration Project as an example, the stakeholders include attractions manager, residents, Oxford County Council, Oxford City Council, English Heritage (Historical England), the Trevor Osborne Group, Oxford Castle Ltd. and Oxford Preservation Trust. Nevertheless, the attractions in China link very closely to the local community. The attractions in China employ a large number of people and attract a million visitors to, for example, SPGWC. The attraction is one of the major economic poles for local cities and has a certain influence on the local community. The attractions belong to the government which may link them more closely to the local political community, and work with other government departments to hold more social functions, for example, the temple fairs and festivals.

\subsection{Governance Dimension}

\subsubsection{Current Situations}

Both the UK and China use a planning system to regulate heritage tourism planning, although they have various and differing planning authorities. The concept of sustainable planning has been introduced into both countries. There are, however, differences between the issues they have faced and their management.

Heritage tourism has developed gradually in the UK, although it is difficult to adequately maintain heritage development and conservation. When heritage development meets a problem, attractions in China have a stronger tendency to address these faster, while the same problem may take more time and cost than in the UK. However, China has a tendency to pay more attention to economic benefits, which harms the interests of the local community and destroys the heritage site in some cases.

Ownership and governance of built heritage attractions vary hugely between these two countries. Built heritage sites belong to and are operated by different parties in the UK: government, private, charity and trust and other public sector parties. This research found trust-managed heritage sites 
have become a strong trend in the UK and they seem to have an increasing number of heritage sites. Meanwhile, in China, most heritage sites belong to the government or are operated by the government, directly or indirectly, rather than the private sector. However, few trusts take charge of heritage sites.

\subsubsection{Questionnaire Survey}

Within the questionnaire survey, the legal basis for heritage attractions has the highest importance score in both countries. There is virtually no difference between Chinese and British views on urban planning. Attractions in the UK tend to have a stronger view on the involvement of key stakeholders, producing sustainability documents and the legal basis for heritage protection. The planning and legal systems differ markedly between the two countries: the UK attractions tend to emphasize the importance of social equality more than in China, and they have established more mature heritage management systems than built heritage attractions in China.

\subsubsection{Case Studies}

Within the case studies, attractions in both countries have similar sub-indicator interview performance on troubleshooting ability. Attractions in the UK tend to have a much higher interview performance on planning performance and a slightly higher interview performance on attraction management. Attractions in the UK are at least trying to involve locals and ensure transparency by publishing planning decisions thereby placing them in the public domain, and making them open to discussion to some extent. Attractions in China have a tendency to inform local communities of the planning decisions they have made with limited stakeholder involvement. It would be no surprise that attractions in the UK have established a relatively comprehensive management system and that they have more experience on built heritage development and management based on previous research. Attractions in both countries are influenced by external factors in planning performance in terms of local planning regulations and contexts. Since MJ and SPGWC are under the government system, their planning development and permissions are controlled and supported by local government.

\subsection{Variations in Key Sustainability Indicators between the UK and China}

In questionnaire, the research compared the variations between indicator types in the UK and China and identified several important similarities and differences. Overall, attractions in both countries recognise the importance of sustainability in relation to built heritage attractions, but attractions in the UK tend to emphasize the importance of the indicators associated with social equality and establishing a mature heritage management system. This may result from attractions needing more support from local residents in the UK because local residents can influence attractions' decisions. Furthermore, attractions in the UK are less financially associated with local government than those in China; the UK attractions are also more responsible for their own profit and loss. Attractions in the UK have a more mature experience than those in China in terms of controlling tourism numbers and maintaining built heritage. In contrast, attractions in China tend to have stronger views on: external funding, possessing an environmental management system, and managing traffic congestion during peak tourism periods and attraction management. This may be because most attractions in China are owned by government bodies, so attractions receive more financial support from government and, as such, they are strongly influenced by local government. The Chinese Tourist Attraction Rating Categories have enabled more attractions in China to implement an environmental management system compared to the UK. Attractions in both countries pay attention to environmental management. In the UK, most buildings need to apply for the Dwelling Carbon Dioxide Emission Rate, while in China, local government also encourages building owners to use energy and water efficient systems by giving them financial subsidies.

In case study, in relation to the comparative study, Orbasli [23] noted that heritage tourism can be an alternative solution for promoting the local economy; this research confirmed that attractions in China have a tendency to pay more attention to economic benefits than attractions in the UK, 
by attracting more visitors and only controlling carrying capacity in a limited way. Furthermore, attractions in the UK have more funding sources for heritage conservation than those in China. In contrast to the existing research on community involvement reported by Yung and Chan [55], this research indicates ineffective public participation in heritage conservation in China. Attractions in the UK have a wider range of stakeholders involved in heritage regeneration projects, but this can lead to time-consuming and ineffective communication. Thurley [56] demonstrated the development history of heritage conservation in the UK; this research verifies the relatively mature heritage market in the UK. Few research studies have focused on heritage conservation management systems in China and other emerging, as opposed to mature, cultural heritage markets.

\section{Discussion}

Overall, three sets of indicators are suitable and practical to be used for measuring the overall sustainability of built heritage attractions, while the third set of indicators is the most suitable. There are still certain limitations inherent in using qualitative data and other aspects so that the indicators would need to be used with descriptive and assessment tools.

From aspect of data collections, there was a practical problem with data accessibility when conducting the survey. Some important data needed to be collected but this was not possible because the interviewees could not provide the information. From the built heritage attraction management questionnaire survey conducted prior to the main case studies, the research findings could only assess the 36 responding attractions and cannot extrapolate the views of the attractions that did not respond. For the main case studies, in all cases, it was very difficult to stimulate more than one stakeholder (managers, third parties or visitors) to participate in the survey. Some attraction stakeholders agreed to participate in the survey, but other important stakeholders did not wish to participate, resulting in the researcher having to abandon that particular case. Different stakeholders had different levels of influence on the actions of the attraction management which may have led them to hold different views of the issues. The personal values and the backgrounds of the stakeholders may also contribute to variations in the results. Furthermore, respondents from all four case studies raised concerns about the potential adverse impact of participating in this research. Therefore, it was not easy to collect all the data suggested in the sub-indicators, and some data related to financial results seemed to be very sensitive for interviewees.

In terms of analytical framework, the questionnaire survey tested a set of indicators based on the attraction management's perspective without the involvement of other stakeholders; therefore, the range of opinions and the weighting of the indicators might vary if other stakeholders are involved. The development of indicators may design subjectivity due to various research were proposed different indicators. As each indicator might be used in more than one dimension at the same time, it is challenging to decide in which dimension these indicators should be placed.

Moreover, the comparative research of the main case studies is limited by the number of case studies and the fact that only four cases were involved in the research. Therefore, the research is mainly looking for overall trends and any outstanding findings. Furthermore, for the case studies involving two organizations, one of the two organizations' weightings and scores may be missing from the data collection; for example, in the cases of MJ and OCHS. Therefore, in that instance, many scores are the means of the results from both sites and some scores use one site to represent the entire case study when data from the other site was not accessible. Therefore, it may not be very fair to use these data to reflect the true development of this site, as the above method may distort the findings when comparing very different elements of the case study.

This research took two mitigation measures to limit the bias during the research stages. Firstly, this research approached targeted sites frequently for collecting more questionnaire responses. In the UK, the researcher employed the Google Documents website to design and distribute the questionnaire. The online survey was conducted twice because of low response rates; one of the authors visited some heritage sites to suggest visitors fill in the questionnaire. In China, the questionnaire survey was 
supported by the local government for data collection to improve the response rate. Secondly, given that the questionnaire survey tested a set of indicators based on the attraction management's perspective, the case study research involves opinions from other stakeholders. Although the comparative analysis only compares 36 heritage attractions, these sites were selected by various categories representatively.

\section{Conclusions and Future Development}

This research identified the variations in terms of the importance of key sustainable indicators between the UK and China, by comparing the current situations, questionnaire survey results and case studies. The combination of several methodologies for the analysis ensured that the core of the research was processed and suitable to apply overall. Without this complicated analytical apparatus, the understanding of the interactions would not have been possible. The analytical framework was sufficiently robust to identify the variety of issues within the sustainability of built heritage attractions and sufficiently flexible to accommodate the four case studies. Furthermore, although with certain limitations, the analysis process performed as expected and identified additional factors and components which influence sustainability.

The most significant contributions of this research are that it has defined sustainability in relation to built heritage attractions, and it has helped to develop three set of indicators to examine the relative importance of various aspects of sustainability, and to apply the indicators into the questionnaire survey and case study. This article highlights the potential role of sustainability indicators as a vehicle for implementing a sustainability appraisal approach for built heritage attractions. The application of sustainability indicators can open up new directions for both theoretical and empirical studies in the field of sustainability appraisal of built heritage attractions, which could substantially enhance the initial foundations established in this work.

The traditional dimensions of sustainability include three pillars, namely the economic, social and environmental [11], but this research has also considered governance as an independent dimension when applying to heritage. If there were no interaction and integration among the economic, environmental and social dimensions, it would be difficult to achieve sustainability or to appraise it. The meaning of "governance" was transferred from traditional management practice within organizations to extend to a larger scope in planning practice. It can refer to the arrangement of certain policies and services [57]. To achieve a holistic assessment, appropriate management is the key catalyst to sustainable development in practice. Furthermore, this research has challenged the opinions that that cultural values are over compromised for commercial gain [28]. After reviewing the sustainability results from attractions in both countries, the importance of cultural values was confirmed, and they are not always compromised.

The set of indicators has been designed based on the above dimensions. The application of a sustainability appraisal approach for built heritage attractions may provide guidance to decision makers to identify the sustainability performance of built heritage attractions, to develop a holistic approach to heritage tourism and strategies, and to guide and monitor heritage conservation funding allocation. The next stage of the research on sustainability appraisal within built heritage attractions involves more in-depth case studies.

Author Contributions: Conceptualization, W.R.; Methodology, W.R.; Software, W.R.; Validation, W.R.; Formal Analysis, W.R.; Investigation, W.R.; Resources, W.R.; Data Curation, W.R.; Writing-Original Draft Preparation, W.R.; Writing-Review and Editing, F.H.; Visualization, F.H.; Supervision, F.H.; Project Administration, W.R.; and Funding Acquisition, F.H.

Funding: This research was funded by the National Major Research and Development Program of the Ministry of Science and Technology; Synergistic Research on Ecological Protection and Community Development of Heritage Sites (Number: 2016YFC0503308); World Heritage Institute of Training and Research-Asia and Pacific, The UNESCO World Heritage and Sustainable Tourism Programme; Scientific Research Fund of Shanghai Peak Plateau (College of Architecture and Urban Planning Tongji University). 
Acknowledgments: We would like to thank John Glasson and Brian Goodey for their contribution to the research and detailed comments during the first draft; three reviewers for their helpful comments and suggestions and support from World Heritage Institute of Training and Research-Asia and Pacific.

Conflicts of Interest: The authors declare no conflict of interest.

\section{Appendix A}

\section{Appendix A.1. Questionnaire Survey}

\section{Section A: About Your Attraction}

1.1 The name of your attraction

1.2 How many tourists visited your attraction in 2012 (or the number of tourists in 2011 if 2012 data is not yet available)?

1.3 How many people are employed by your attraction? How many of them are seasonal employees? How many of them are from the 'local area'? (The definition of local area in this research is an area within 10 miles radius of the attraction). Total employees, of which seasonal employees, and local employees

1.4 Which department/ position takes charge of environmental management issues?

1.5 Your Email Telephone number

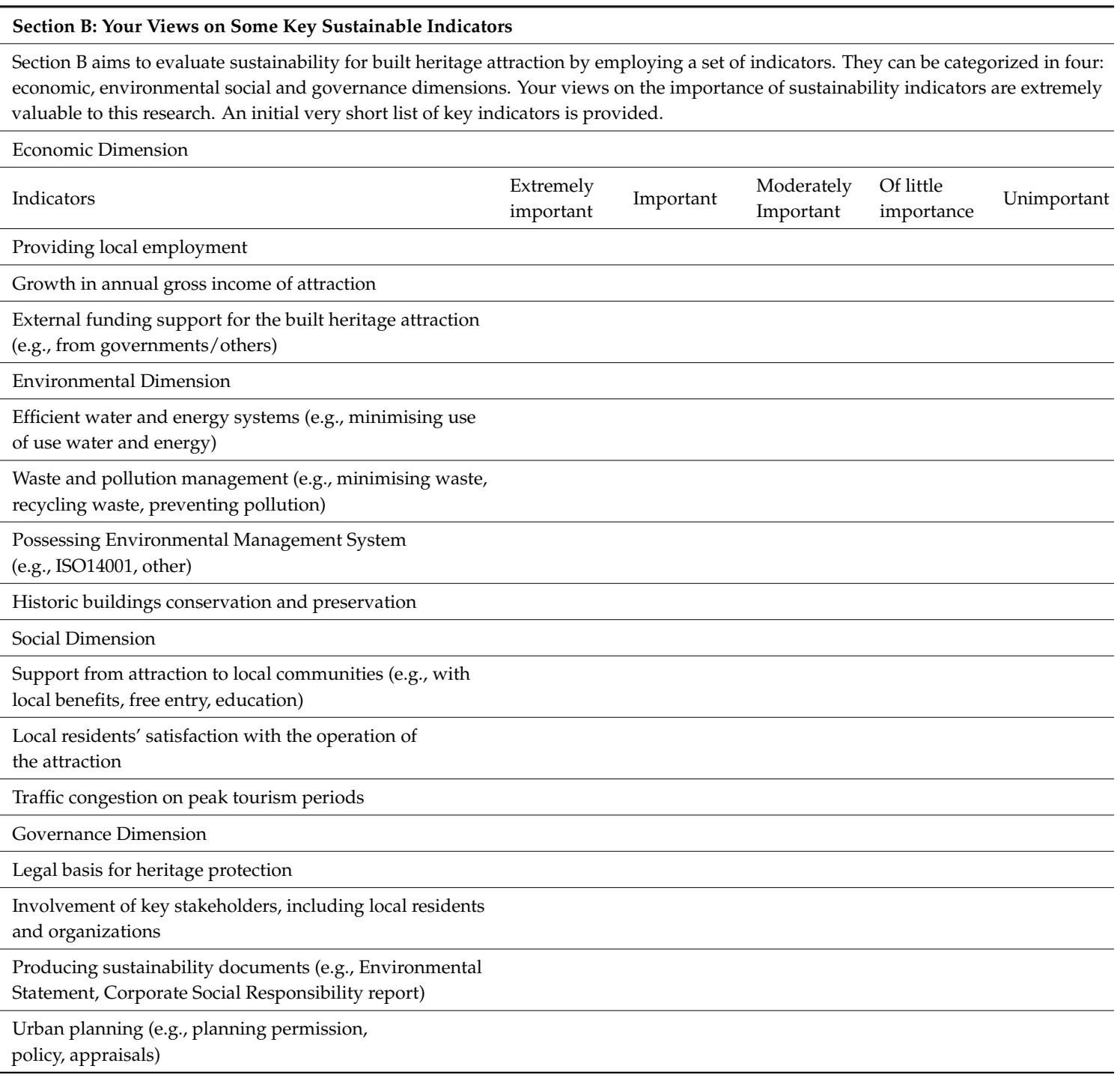

Please specify any other indicators which you think are important but are not listed above. 


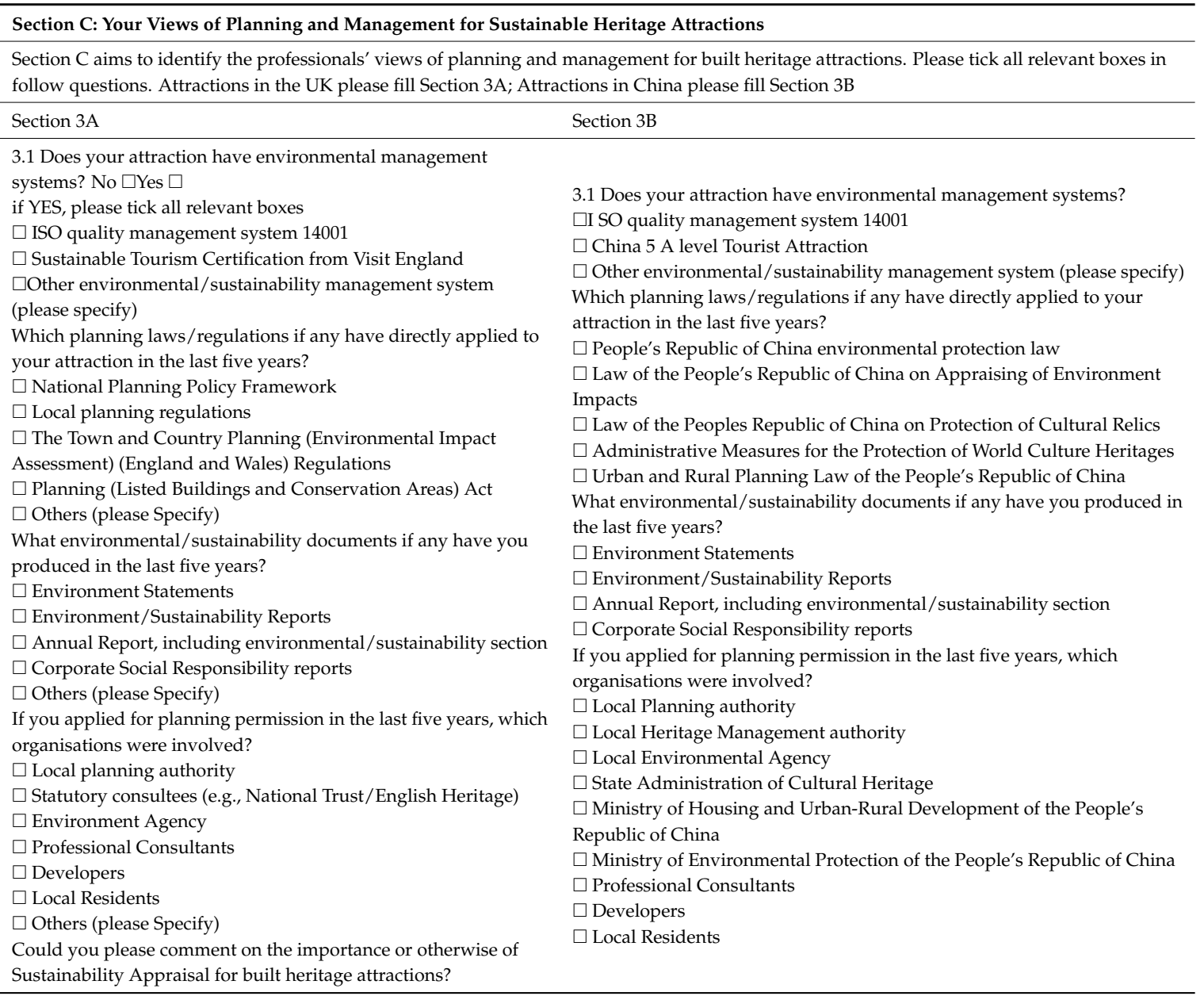

\section{Appendix A.2. Key Interview Questions of Case Studies}

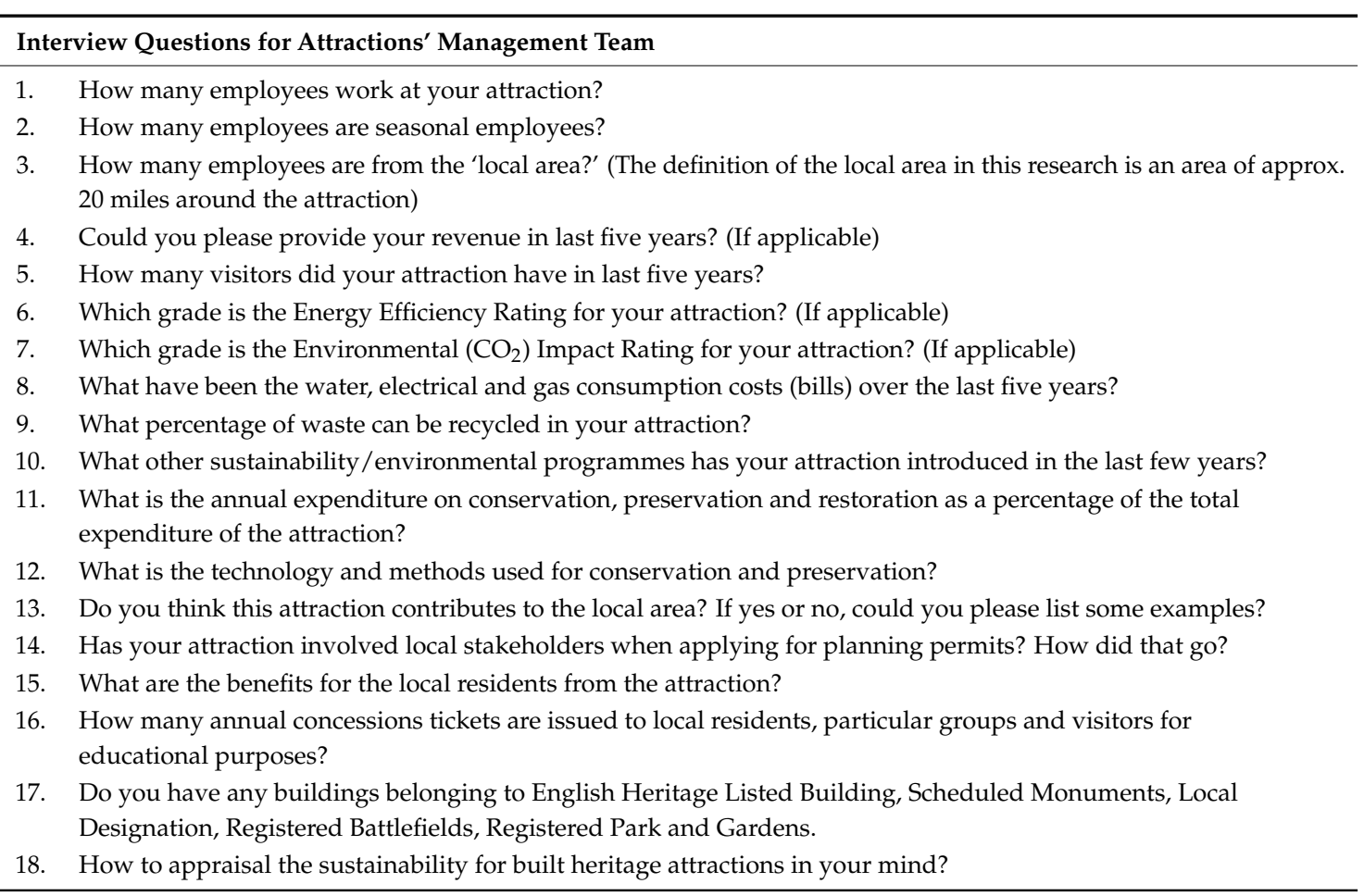




\section{Interview Questions for Third Party}

1. Could you please explain the individual attraction planning management system of National Trust?

2. Do you think this attraction contributes to the local area? If yes or no, could you please list some examples?

3. Have you been involved in this attraction in relation to planning permits in the last five years? If yes, could you please describe your involvement?

4. Have you been involved with this attraction in other events, activities, and programmes?

5. If the attraction has applied for planning permission in the last five years, which organisations were involved? Were you involved in the decision making process?

6. Which planning laws/regulations, if any, have been directly applied to the attraction in the last five years?

7. Has the attraction applied environmental planning (such as EIA) in the last five years? What do you think about that?

8. Are there any buildings belonging to English Heritage Listed Building, Scheduled Monuments, Local Designation, Registered Battlefields, Registered Park and Gardens.

9. What is the development plan for the attraction?

10. How planning management may benefit to the sustainability for built heritage attraction?

11. How to appraisal the sustainability for built heritage attractions in your mind?

\section{Basic Questions for Visitors}

1. Where are you come from?

2. Could you please give more comments and suggestions in relation to sustainability for this attraction?

3. Do you think this attraction contributes to the local area? If yes or no, could you please list some examples?

4. Have you been involved with this attraction in other events, activities, and programmes?

5. How to appraisal the sustainability for built heritage attractions from your min

6. Please rate the following in order of satisfaction to your attraction, with 10 being the most satisfy and 1 being the least unsatisfied.

$\begin{array}{llllllllll}1 & 2 & 3 & 4 & 5 & 6 & 7 & 8 & 9 & 10\end{array}$


Table A1. Development of indicators in this research.

\begin{tabular}{|c|c|c|c|}
\hline & $\begin{array}{l}\text { First Set of Indicators for } \\
\text { Questionnaire Survey }\end{array}$ & Second Set of Indicators for Pilot Case Study & Third Set of Indicators for Main Case Study \\
\hline \multirow{4}{*}{$\begin{array}{l}\text { Economic } \\
\text { dimension }\end{array}$} & Providing local employment & $\begin{array}{l}\text { Indicators of employment } \\
\text { - Total number of built heritage positions created directly by } \\
\text { the attraction } \\
\text { - Percentage of built heritage positions which provide permanent } \\
\text { employment for the full year } \\
\text { - Percentage of professionals who come from the local area }\end{array}$ & $\begin{array}{l}\text { Indicators of employment } \\
\text { - Percentage of built heritage tourist industry positions which } \\
\text { provide permanent employment for the full year } \\
\text { - Percentage of staff who come from the local town/city }\end{array}$ \\
\hline & $\begin{array}{c}\text { Growth in annual gross income } \\
\text { of attraction }\end{array}$ & $\begin{array}{l}\text { Indicator of financial health } \\
\text { - } \quad \text { Visitor numbers } \\
\text { - Total net (revenue-costs) } \\
\text { - } \quad \text { Visitor numbers and net growth }\end{array}$ & $\begin{array}{l}\text { Indicator of financial health } \\
\text { - Total net profit of an attraction divided by attraction } \\
\text { employee numbers } \\
\text { - Net profit growth rate }\end{array}$ \\
\hline & $\begin{array}{l}\text { External funding support for } \\
\text { the built heritage attraction }\end{array}$ & & \\
\hline & & & $\begin{array}{l}\text { Indicator of visitors } \\
\text { - The actual visitor numbers compare to the designed tourism } \\
\text { carrying capacity of the attraction } \\
\text { - Tourist numbers of an attraction divided by attraction } \\
\text { employee numbers }\end{array}$ \\
\hline \multirow{4}{*}{$\begin{array}{l}\text { Environmental } \\
\text { dimension }\end{array}$} & $\begin{array}{l}\text { Efficient water and energy } \\
\text { systems }\end{array}$ & $\begin{array}{l}\text { Indicator of green/sustainability initiatives } \\
\text { - } \quad \text { Energy efficiency rating } \\
\text { - } \quad \text { Environmental }\left(\mathrm{CO}_{2}\right) \text { impact rating } \\
\text { - Water, electrical and gas consumption trends } \\
\text { - } \quad \text { Waste and water recycle rate }\end{array}$ & $\begin{array}{l}\text { Indicator of environmental management } \\
\text { - } \quad \text { Environmental management system } \\
\text { - Water, electrical and gas consumption trends per annum } \\
\text { - Waste recycle rate per annum }\end{array}$ \\
\hline & $\begin{array}{l}\text { Waste and pollution } \\
\text { management }\end{array}$ & & \\
\hline & $\begin{array}{l}\text { Possessing an environmental } \\
\text { management system }\end{array}$ & & \\
\hline & $\begin{array}{c}\text { Historic buildings' } \\
\text { conservation and preservation }\end{array}$ & $\begin{array}{l}\text { Indicator of historic buildings } \\
\text { - Conservation and preservation expenditure on conservation, } \\
\text { - Teservation and restoration } \\
\text { - Technology and method of conservation and preservation }\end{array}$ & $\begin{array}{l}\text { Indicator of historic buildings conservation and preservation } \\
\text { - Percentage of annual expenditure on conservation, } \\
\text { preservation and restoration as a proportion of the total } \\
\text { expenditure of attraction } \\
\text { - Attraction conservation system }\end{array}$ \\
\hline
\end{tabular}


Table A1. Cont.

\begin{tabular}{|c|c|c|c|}
\hline & $\begin{array}{l}\text { First Set of Indicators for } \\
\text { Questionnaire Survey }\end{array}$ & Second Set of Indicators for Pilot Case Study & Third Set of Indicators for Main Case Study \\
\hline \multirow[t]{3}{*}{$\begin{array}{c}\text { Social } \\
\text { dimension }\end{array}$} & $\begin{array}{l}\text { Support from attraction to } \\
\text { local communities }\end{array}$ & $\begin{array}{l}\text { Indicator of key stakeholders' involvement } \\
\text { - The attitudes towards attractions from the local community, } \\
\text { tourism authority, and planning authority } \\
\text { - Local people decision involvement } \\
\text { - Concessions for local residents, particular groups and visitors } \\
\text { - for educational purposes as a proportion of total visitors } \\
\text { Number of local workers }\end{array}$ & $\begin{array}{l}\text { Indicator of key stakeholders' involvement } \\
\text { - } \quad \text { Social involvement } \\
\text { - Annual concession to local residents, particular groups and } \\
\text { visitors for educational purposes as a proportion of } \\
\text { total visitors }\end{array}$ \\
\hline & $\begin{array}{l}\text { Local residents' satisfaction } \\
\text { with the operation of } \\
\text { the attraction }\end{array}$ & & $\begin{array}{l}\text { Indicator of key stakeholders' attitudes } \\
\text { - The attitudes towards attractions from the third parties (local } \\
\text { community, volunteers, and other authorities) } \\
\text { - The attitudes towards attractions from the visitors }\end{array}$ \\
\hline & $\begin{array}{l}\text { Traffic congestion during peak } \\
\text { tourism periods }\end{array}$ & & \\
\hline \multirow{6}{*}{$\begin{array}{l}\text { Governance } \\
\text { dimension }\end{array}$} & $\begin{array}{l}\text { Involvement of key } \\
\text { stakeholders }\end{array}$ & & \\
\hline & $\begin{array}{l}\text { Producing sustainability } \\
\text { documents }\end{array}$ & & \\
\hline & Urban planning & $\begin{array}{l}\text { Indicator of planning } \\
\text { - } \quad \text { Planning documentations } \\
\text { - } \quad \text { Planning process } \\
\text { - } \quad \text { Transparency and accountability } \\
\end{array}$ & $\begin{array}{l}\text { Indicator of planning } \\
\text { - } \quad \text { Planning performance }\end{array}$ \\
\hline & $\begin{array}{l}\text { Legal basis for } \\
\text { heritage protection }\end{array}$ & & \\
\hline & & & $\begin{array}{l}\text { Indicator of troubleshooting ability } \\
\text { - The ability to balance the relationship between development } \\
\text { and preservation }\end{array}$ \\
\hline & & & $\begin{array}{l}\text { Indicator of attraction management } \\
\text { - Attraction management }\end{array}$ \\
\hline
\end{tabular}


The initial set of indicators were developed from the attraction managers' questionnaire survey in 2013. The researcher could not collect full, accurate data according to the initial research design and this meant that a case study analysis became impractical. From the second set indicators to the third set of indicators, sub-indicators were added to support the indicator for measuring more logicality. In the economic dimension, Growth in annual gross income of attraction and External funding support for the built heritage attraction were merged into Indicator of financial health, the merged indicator can evaluate the growth and economic benefits of heritage attraction, data of External funding support for the built heritage attraction were challenging to calculate for individual attraction. In the environmental dimension, efficient water and energy systems, Waste and pollution management and possessing an environmental management system were merged into Indicator of green/sustainability initiatives. In the Social dimension, Support from attraction to local communities and Local residents' satisfaction with the operation of the attraction were merged into Indicator of key stakeholders involvement. Traffic congestion during peak tourism periods was deleted because of lack of evidence on the relationship between traffic and heritage sustainability, especially the traffic impacts may be limited if a small heritage site in the large area. In the Governance dimension, Involvement of key stakeholders was relocated to Social dimension due to it being closer to the latter dimension. Producing sustainability documents and Legal basis for heritage protection were deleted for unpractical to measure, and their functions related to planning were merged into indicator of planning.

From the second to third set of indicators, some changes were made to the research approach after the site survey was conducted at Chastleton House and Garden. In the economic dimension, the sub-indicator of the total number of built heritage employment positions created directly by the attraction was deleted because large attractions may provide more positions than small attractions which would lead to an unfair comparison. Instead, the study uses the percentage of built heritage tourist industry positions which provide permanent employment for the full year to represent this number. This puts large and small attractions on the same level, and the data on employee numbers could be collected and not influence the scores of the revised indicators. The indicator of financial health was divided into two sub-indicators: the indicator of financial health and the indicator of visitors. The sub-indicator of visitor numbers and total net profit (revenue-costs) was deleted as this might lead to an unfair comparison between large and small attractions by using the pure numbers. The sub-indicator measurements were changed into a percentage. For example, the sub-indicator of total net profit of an attraction divided by the attraction's employee numbers considers the relationship between visitor numbers and total net profit; the sub-indicator of tourist numbers of an attraction divided by the attraction's employee numbers considers the relationship between visitor numbers and employee numbers. All the above data were collected from the pilot study, and these indicators can be used as an index for measuring the financial efficiency of the employee contribution within human resources management. In other words, how much net profit would be contributed to an attraction by one employee, and how many visitors would one employee be able to manage? The revised sub-indicator of actual visitor numbers compared to the designed tourism carrying capacity of the attraction considers the ability to manage the number of visitors to an attraction. In the final research, employment, financial health and visitors were selected to be the indicators for assessing the economic performance of built heritage attractions.

In the environmental dimension, the wording of the indicator of green/sustainability initiatives changed to the indicator of environmental management because the latter suggested a more specific focus on environmental management. The sub-indicator of energy efficiency rating and environmental $\left(\mathrm{CO}_{2}\right)$ impact rating received more popularity in the housing assessment sector in the UK, but not all historic housing has both ratings. These two sub-indicators were then merged into the environmental management system because data on the latter would be more accessible and it would be practical and more easily understandable for the majority of stakeholders. The indicator of historic buildings' conservation and preservation changed from expenditure on conservation to the percentage spent on conservation as a proportion of total expenditure for the same reason as above; it was thought that a 
percentage rate comparison between different sizes of attraction would be fairer than just using the numbers. However, it was still difficult to collect data for this indicator. The question of conservation and preservation technologies also presented a challenge during data collection and it did not cover the full scope of attraction conservation, so it was changed to "attraction conservation system". In the final research, environmental management and historic buildings' conservation and preservation were selected to be the indicators for assessing the environmental performance of built heritage attractions.

In social dimension, the indicator of key stakeholders' involvement was divided into two sub-indicators to improve its measurability: the sub-indicators of social involvement and the sub-indicators of annual concessions to local residents, particular groups and visitors for educational purposes as a proportion of total visitors. The sub-indicator of local peoples' involvement in decisions was changed to the sub-indicator of social involvement to enlarge the scope of local influence. The sub-indicator of the number of local workers was deleted because it overlapped with indicators in the economic dimension. The indicator of key stakeholders' attitudes includes two sub-indicators on attitudes: attitudes towards the attractions from third parties (local community, volunteers, and other authorities) and attitudes towards the attractions from visitors. In the final research, key stakeholders' involvement and attitudes were selected to be the indicators for assessing the social performance of built heritage attraction.

In governance dimension, the indicator of planning was divided into three sub-indicators: the indicator of planning, the indicator of troubleshooting ability and the indicator of attraction management. It was difficult to collect data on the sub-indicators of planning documentation, planning process, transparency and accountability, and effectiveness and efficiency in the pilot study, and the criteria for measuring the planning indicators were difficult to set up and apply. Thus, the sub-indicator of planning performance was used to replace all the previous indicators in planning to consider the performance on regulatory compliance, planning transparency, accountability and effectiveness. In addition, a new indicator of troubleshooting ability was added, with the aim of measuring the ability to balance the relationship between development and preservation of an attraction using the following criteria: in relation to issues of development and preservation, the attraction can respond to issues quickly, address the issues practically, and the results will be acceptable to most of the stakeholders. A new indicator of attraction management was also added, with the aim of measuring the attraction's management using the following criteria: The attraction should have a clear vision for development, practical financial forecasting; it should use staff and working resources efficiently, and maintain staff satisfaction with the attraction management. In the final research, planning performance, the ability to balance the relationship between development and preservation and attraction management were selected to be the indicators for achieving holistic assessment of the governance dimension.

\section{References}

1. Graham, B. Heritage as Knowledge: Capital or Culture? Urban Stud. 2002, 39, 1003-1017. [CrossRef]

2. Barthel-Bouchier, D. Cultural Heritage and the Challenge of Sustainability; Left Coast Press: Oxon, UK, 2012.

3. Glasson, J.; Therivel, R.; Chadwick, A. Introduction to Environmental Impact Assessment; Taylor \& Francis: Oxfordshire, UK, 2013.

4. Nocca, F. The Role of Cultural Heritage in Sustainable Development: Multidimensional Indicators as Decision-Making Tool. Sustainability 2017, 9, 1882. [CrossRef]

5. European Environmental Agency. Environmental Indicator Report 2012-Ecosystem Resilience and Resource Efficiency in a Green Economy in Europe/Part 1; European Environmental Agency: Copenhagen, Denmark, 2012.

6. English Tourism Council. Strategy for Sustainable Development, Securing the Future; English Tourism Council: London, UK, 2002.

7. Stubbs, M. Heritage-sustainability: Developing a methodology for the sustainable appraisal of the historic environment. Plan. Pract. Res. 2004, 19, 285-305. [CrossRef]

8. United Nations World Tourism Organization. Indicators of Sustainable Development for Tourism Destinations: A Guidebook; Organisation Mondiale du Tourisme: Madrid, Spain, 2004. 
9. Verma, P.; Raghubanshi, A.S. Urban sustainability indicators: Challenges and opportunities. Ecol. Indic. 2018, 93, 282-291. [CrossRef]

10. United Nations World Tourism Organization. International Network of Sustainable Tourism Observatories (INSTO). 2018. Available online: http:/ /insto.unwto.org/about/ (accessed on 7 June 2018).

11. Ren, W. Developing a Sustainability Appraisal for Built Heritage Attractions; Oxford Brookes University: Oxford, UK, 2016.

12. World Bank. How We Classify Countries. 2012. Available online: http://data.worldbank.org/about/ country-classifications (accessed on 1 January 2012).

13. United Nations Educational, Scientific and Cultural Organization. World Heritage List. 2016. Available online: http:/ / whc.unesco.org/en/list (accessed on 17 June 2016).

14. Tunbridge, J.E.; Ashworth, G.J. Dissonant Heritage: The Management of the Past as a Resource in Conflict; John Wiley: Hoboken, NJ, USA, 1996.

15. Wall, G.; Mathieson, A. Tourism: Change, Impacts, and Opportunities; Pearson Prentice Hall: Upper Saddle River, NJ, USA, 2006.

16. Brown, F. Tourism Reassessed: Blight or Blessing; Taylor \& Francis: Oxfordshire, UK, 2010.

17. Mason, P. Tourism Impacts, Planning and Management; Taylor \& Francis: Oxfordshire, UK, 2015.

18. United Nations. Our Common Future: Report of the World Commission on Environment and Development-Brundtland Report; United Nations: New York, NY, USA, 1987.

19. Theobald, W.F. Global Tourism: The Next Decade; Butterworth-Heinemann Limited: Oxford, UK, 1994.

20. Hall, C.M. Tourism Planning: Policies, Processes and Relationships; Pearson/Prentice Hall: Upper Saddle River, NJ, USA, 2008.

21. United Nations: Economic Social Commission for Asia and the Pacific. Statistical Yearbook for Asia and the Pacific 2009; United Nations Publications: New York, NY, USA, 2010.

22. Waligo, V.M.; Clarke, J.; Hawkins, R. Implementing sustainable tourism: A multi-stakeholder involvement management framework. Tour. Manag. 2013, 36, 342-353. [CrossRef]

23. Orbasli, A. Tourists in Historic Towns: Urban Conservation and Heritage Management; Taylor \& Francis: Oxfordshire, UK, 2002.

24. United Nations Development Programme. Governance Indicators: A Users' Guide, 2nd ed.; United Nations Development Programme: New York, NY, USA, 2014.

25. Gibson, B.; Hassan, S.; Tansey, J. Sustainability Assessment: Criteria and Processes; Taylor \& Francis: Oxfordshire, UK, 2013.

26. Bond, A.; Morrison-Saunders, A.; Pope, J. Sustainability assessment: The state of the art. Impact Assess. Proj. Apprais. 2012, 30, 53-62. [CrossRef]

27. Gasparatos, A.; Scolobig, A. Choosing the most appropriate sustainability assessment tool. Ecol. Econ. 2012, 80, 1-7. [CrossRef]

28. Ness, B.; Urbel-Piirsalu, E.; Anderberg, S.; Olsson, L. Categorising tools for sustainability assessment. Ecol. Econ. 2007, 60, 498-508. [CrossRef]

29. Gasparatos, A.; El-Haram, M.; Horner, M. A critical review of reductionist approaches for assessing the progress towards sustainability. Environ. Impact Assess. Rev. 2008, 28, 286-311. [CrossRef]

30. Singh, R.K.; Murty, H.R.; Gupta, S.K.; Dikshit, A.K. An overview of sustainability assessment methodologies. Ecol. Indic. 2012, 15, 281-299. [CrossRef]

31. Therivel, R.; Paridario, M.R. The Practice of Strategic Environmental Assessment; Taylor \& Francis: Oxfordshire, UK, 2013.

32. Urry, J.; Larsen, J. The Tourist Gaze 3.0; SAGE Publications: Thousand Oaks, CA, USA, 2011.

33. McKercher, B.; Ho, P.S.Y. Assessing the Tourism Potential of Smaller Cultural and Heritage Attractions. J. Sustain. Tour. 2006, 14, 473-488.

34. Timothy, D.J.; Boyd, S.W. Heritage Tourism; Prentice Hall: Upper Saddle River, NJ, USA, 2003.

35. Timothy, D.J.; Nyaupane, G.P. Cultural Heritage and Tourism in the Developing World: A Regional Perspective; Taylor \& Francis: Oxfordshire, UK, 2009.

36. Bizzarro, F.; Nijkamp, P. Cultural heritage and urban revitalization: A meta-analytic approach to urban sustainability. In Evaluation in Planning: Facing the Challenge of Complexity; Lichfield, N., Barbanente, A., Borri, D., Khakee, A., Prat, A., Eds.; Springer: Dordrecht, The Netherlands, 1998; pp. 193-211. 
37. Teutonico, J.M.; Matero, F. (Eds.) Managing Change: Sustainable Approaches to the Conservation of the Built Environment: 4th Annual US/ICOMOS International Symposium Organized by US/ICOMOS, the Graduate Program in Historic Preservation of the University of Pennsylvania, and the Getty Conservation Institute, Philadelphia, Pennsylvania, April, 2001; Getty Conservation Institute: Los Angeles, CA, USA, 2003.

38. Rodwell, D. Sustainability and the Holistic Approach to the Conservation of Historic Cities. J. Archit. Conserv. 2003, 9, 58-73. [CrossRef]

39. United Nations Educational Scientific and Cultural Organization. Convention Concerning the Protection of the World Cultural and Natural Heritage. Thirty-Sixth Session Saint Petersburg, Russian Federation; UNESCO: Paris, France, 2012.

40. Pope, J.; Bond, A.; Hugé, J.; Morrison-Saunders, A. Reconceptualising sustainability assessment. Environ. Impact Assess. Rev. 2017, 62, 205-215. [CrossRef]

41. Agol, D.; Latawiec, A.E.; Strassburg, B.B.N. Evaluating impacts of development and conservation projects using sustainability indicators: Opportunities and challenges. Environ. Impact Assess. Rev. 2014, 48, 1-9. [CrossRef]

42. Canter, L.W.; Atkinson, S.F. Multiple uses of indicators and indices in cumulative effects assessment and management. Environ. Impact Assess. Rev. 2011, 31, 491-501. [CrossRef]

43. Globe, G. Standard Criteria and Indicators. 2015. Available online: http://greenglobe.com/standard/ (accessed on 15 October 2015).

44. Airey, D.; Chong, K. Tourism in China: Policy and Development Since 1949; Taylor \& Francis: Oxfordshire, UK, 2011.

45. United Nations Development Programme. Cultural Diversity and Biodiversity for Sustainable Development; United Nations Environment Programme: Nairobi, Kenya, 2003.

46. Walters, J.L. Doing Qualitative Research: A Practical Handbook. Adult Educ. Q. 2006, 56, 166-167. [CrossRef]

47. Meadows, L.M.; Morse, J.M. Constructing Evidence within the Qualitative Project. J. Qual. Res. 2001. [CrossRef]

48. Creswell, J.W. Research Design: Qualitative, Quantitative, and Mixed Method Approaches; SAGE: Thousand Oaks, CA, USA, 2009; p. 103.

49. Historic England. HERITAGE COUNTS 2017 Heritage and the Economy; London National Office: London, UK, 2017.

50. China National Tourism Administration. Tourist Attraction Rating Categories of China; China Tourism Press: Beijing, China, 2009.

51. Historic England. Local Designation. 2018. Available online: https://www.historicengland.org.uk/listing/ what-is-designation/local/ (accessed on 7 July 2018).

52. Historic England. What Is Listing? 2018. Available online: https://www.historicengland.org.uk/listing/ what-is-designation/ (accessed on 7 July 2018).

53. Shepherd, R.J.; Yu, L. Heritage Management, Tourism, and Governance in China. J. Herit. Tourism 2015, 9, 185-186.

54. Liu. China's Waste Recycling and the Garbage Classification. 2013. Available online: http:/ / news.solidwaste. com.cn/view /id_51609 (accessed on 21 July 2015).

55. Yung, E.H.K.; Chan, E.H.W. Problem issues of public participation in built-heritage conservation: Two controversial cases in Hong Kong. Habitat Int. 2011, 35, 457-466. [CrossRef]

56. Thurley, S. Men from the Ministry: How Britain Saved Its Heritage; Yale University Press: New Haven, CT, USA, 2014.

57. Brunner, J.; Glasson, J. Contemporary Issues in Australian Urban and Regional Planning. Br. J. Oral Maxillofac. Surg. 2015, 54, 248-252.

(C) 2018 by the authors. Licensee MDPI, Basel, Switzerland. This article is an open access article distributed under the terms and conditions of the Creative Commons Attribution (CC BY) license (http:/ / creativecommons.org/licenses/by/4.0/). 